\title{
Pengaruh Aplikasi Pupuk Organik Cair dan ZPT Alami terhadap Pertumbuhan Tanaman Padi Salibu di Sawah Basah
}

\section{The Effect of Liquid Organic Fertilizer Application and PGRs on the Growth of Salibu} Rice Plants in Wet Field

\author{
Author(s): Marchel Putra Garfansa ${ }^{(1) *} ; \operatorname{Iswahyudi}^{(1)}$ Moh Ramly $^{(1)}$ \\ (1) Universitas Islam Madura \\ * Corresponding author: marchel.sp.mp@gmail.com
}

\begin{abstract}
ABSTRAK
Salibu adalah sistem budidaya dengan tunas tanaman padi yang tumbuh dari tunggul yang telah dipanen, sehingga dapat memberikan tambahan produksi. Penelitian ini bertujuan untuk mengetahui pengaruh pemberian kombinasi pupuk organik cair (POC) Eco Farming dan zat pengatur tumbuh (ZPT) alami pada pertumbuhan padi salibu. Penelitian dilaksanakan di lahan pertanian di Desa Pademawu Timur, Kecamatan Pademawu, Kabupaten Pamekasan. Rancangan yang digunakan adalah rancangan acak kelompok non faktorial yang terdiri dari 4 macam perlakuan yaitu Kontrol (P0), ZPT 14 ml/L (P1), Pupuk Organik Cair (POC) Eco Farming 3 ml/L (P2), dan ZPT 14 ml/L + Pupuk Organik Cair (POC) Eco Farming 3 ml/L (P3). Perlakuan diulang sebanyak 4 kali sehingga diperoleh 16 perlakuan dengan uji lanjut BNT 5\%. Kesimpulan yang diperoleh dalam penelitian ini adalah Pemberian POC yang dikombinasikan dengan ZPT mampu memberikan pertumbuhan yang baik pada tanaman padi salibu.
\end{abstract}

\section{Kata Kunci:}

Padi;

Pupuk organik cair;

\section{Zat pengatur} tumbuh.
Rice;

Liquid organic fertilizer;

Plant growth regulators.
Keywords: $\quad$ Salibu is a cultivation system with rice shoots that grow from harvested stumps so that

\section{ABSTRACT} it can provide additional production. This study aims to determine the effect of giving a combination of Eco Farming liquid organic fertilizer (LOF) and plant growth regulators (PGRs) on the growth of salibu rice. This research was conducted on agricultural land in Pademawu Timur Village, Pademawu District, Pamekasan Regency. The design used was a nonfactorial randomized block design consisting of 4 types of treatment, namely control (PO), PGRs $14 \mathrm{ml} / \mathrm{L}(P 1)$, Eco Farming Liquid Organic Fertilizer (LOC) $3 \mathrm{ml} / \mathrm{L}(P 2)$, and PGRs $14 \mathrm{ml} / \mathrm{L}+$ Liquid Organic Fertilizer (LOC) Eco Farming $3 \mathrm{ml} / \mathrm{L}(P 3)$. The treatment was repeated 4 times in order to obtain 16 treatments with LSD further test. The conclusion obtained in this study is that the provision of LOC combined with PGR is able to provide good growth in salibu rice plants. 


\section{PENDAHULUAN}

Masyarakat Indonesia merupakan negara yang mayoritas petaninya membudidayakan padi sebagai bahan pangan olahan berupa nasi yang sekaligus sebagai makanan pokok sehari-hari. Kebutuhan pokok berupa beras akan meningkat dengan meningkatnya jumlah penduduk. Data statistik yang diperoleh dari Badan Pusat Staistik (BPS) bahkan menunjukkan bahwa luas panen dan produksi beras Indonesia tahun 2019 mengalami penurunan dibandingkan tahun 2018 masing-masing sebesar $6,15 \%$ dan $7,76 \%$. Hal ini tidak terlepas dari terjadinya alih fungsi lahan sawah padi menjadi pemukiman. Upaya pemenuhan kebutuhan pangan Nasional akan beras terus dilakukan. Salah satu strategi yang diterapkan adalah meningkatkan produktivitas padi dapat melalui penerapan inovasi teknologi (Triyogi et al., 2018).

Budidaya padi salibu merupakan salah satu inovasi teknologi yang dapat diterapkan untuk meningkatkan produksi padi per unit area. Padi salibu adalah sistem budidaya dengan tunas tanaman padi yang tumbuh dari tunggul yang telah dipanen, sehingga dapat memberikan tambahan produksi. Terdapat beberapa faktor yang mempengaruhi produktivitas padi salibu antara lain kondisi lingkungan pada lahan. Meskipun penggunaan dosis pupuk sudah banyak diterapkan dalam upaya untuk memberikan kondisi lingkungan yang dibutuhkan tanaman, namun penerapan penelitian dosis pemupukan untuk padi Salibu masih sedikit. Data statistik menunjukkan bahwa adanya penurunan produksi beras sebanyak 105.000 ton setiap tahunnya. Berdasarkan fakta tersebut, maka produktivitas padi perlu ditingkatkan, dan umumnya upaya peningkatan hasil selalu diikuti dengan upaya peningkatan jumlah pupuk kimia yang diberikan pada tanaman. Pemberian pupuk kimia yang dilakukan secara terus menerus dapat menyebabkan penurunan daya dukung lahan seperti tanah menjadi padat dan bersifat masam menyebabkan terjadinya penurunan tingkat kesuburan tanah.

Suatu terobosan teknologi sangat diperlukan untuk dapat meningkatkan produksi padi tanpa merusak lingkungan sehingga diperlukan aplikasi bahan organik. Eco Farming merupakan pupuk atau nutrisi berbahan organik super aktif yang sudah mengandung unsur hara lengkap sesuai kebutuhan tanaman yang juga dilengkapi bakteri positif yang akan menjadi biokatalisator dalam memperbaiki sifat fisik, biologi, dan kimia tanah. Disamping penggunaannya yang praktis dan mudah dibandingkan dengan pupuk kompos, Eco Farming terbukti dapat menekan kebutuhan pupuk lainnya sampai $25 \%$ bahkan $0 \%$ pada tanaman padi (Iswahyudi et al., 2017).

Dalam upaya memaksimalkan pertumbuhan padi Salibu, juga dibutuhkan adanya penambahan Zat Pengatur Tumbuh (ZPT). ZPT digunakan untuk merangsang pertumbuhan akar. Penggunaan pupuk anorganik dalam tanah perlu dikurangi karena jika terus menerus diaplikasikan ke dalam tanah akan menyebabkan tanah menjadi menurun tingkat kesuburannya, jika tanpa diimbangi dengan pemberian bahan organik akan berpengaruh terhadap perubahan sifat fisik tanah. Oleh karena itu perlu untuk memperbaiki tingkat penurunan daya dukung tanah akibat pemberian pupuk anorganik yang berlebihan dengan penambahan bahan organik tanah melalui pupuk organik. Pemberian Pupuk Organik Cair (POC) dan ZPT dapat menjadi kombinasi alternatif dalam penyediaan unsur hara pada tanaman. Berdasarkan hal tersebut, maka penelitian ini bertujuan untuk mengetahui respon pertumbuhan vegetatif tanaman padi salibu menggunakan POC dan ZPT alami. 


\section{METODOLOGI}

Penelitian ini dilaksanakan di lahan pertanian di Desa Pademawu Timur, Kecamatan Pademawu, Kabupaten Pamekasan dengan ketinggian \pm 312 meter di atas permukaan air laut. Suhu rata-rata harian $27-30^{\circ} \mathrm{C}$. Penelitian ini telah dilaksanakan pada bulan Juli 2020 Agustus 2020. Alat yang digunakan dalam penelitian meliputi: cangkul, sabit, gunting, gembor, penggaris, tali rafia, timbangan analitik, oven. Bahan yang digunakan pada penelitian ini antara lain: benih padi varietas IPP3S, Pupuk Organik Cair Eco Farming, zat pengatur tumbuh, pupuk majemuk NPK 15:15:15. Parameter pengamatan meliputi jumlah anakan dan tinggi tanaman. Rancangan yang digunakan adalah Rancangan Acak Kelompok non faktorial yang terdiri dari 4 macam perlakuan yaitu Kontrol (P0), ZPT 14 ml/L (P1), Pupuk Organik Cair (POC) Eco Farming $3 \mathrm{ml} / \mathrm{L}$ (P2), dan ZPT 14 $\mathrm{ml} / \mathrm{L}+$ Pupuk Organik Cair (POC) Eco Farming $3 \mathrm{ml} / \mathrm{L}$ (P3). Perlakuan diulang sebanyak 4 kali sehingga diperoleh 16 perlakuan dengan uji lanjut Beda Nyata Terkecil (BNT) pada taraf 5\%.

\section{HASIL DAN PEMBAHASAN Jumlah Anakan Produktif}

Anakan pada padi tumbuh di antara daun sekunder dan batang. Anakan padi muncul pada saat padi berumur 10 hari setelah tanam. Anakan produktif muncul saat tanaman padi menjelang masuk pembentukan malai atau pada fase generatif, sehingga anakan yang menghasilkan malai dapat disebut sebagai jumlah anakan yang produktif. Hasil uji statistik menunjukkan pada pemberian pupuk organik cair Eco Farm dan ZPT menunjukkan adanya pengaruh terhadap tinggi dan jumlah anakan pada tanaman padi Salibu (Tabel 1). Pada parameter jumlah anakan menunjukkan adanya pengaruh sejak pengamatan pertama. Saat tanaman berumur 14 HSP (Hari Setelah Potong), padi salibu yang diberi perlakuan kontrol menunjukkan hasil yang tidak berbeda nyata jika dibandingkan dengan padi yang di beri perlakuan ZPT dan POC. Akan tetapi ketika tanaman padi diberi perlakuan campuran pupuk POC dengan ZPT menunjukkan hasil yang berbeda nyata dibandingkan dengan perlakuan lainnya. Tanaman yang diberi campuran kombinasi ZPT dan POC secara bersamaan memberikan efektifitas penambahan jumlah anakan yang cukup signifikan terlihat pada Tabel 1.

Tabel 1. Respon jumlah anakan terhadap pemberian POC dan ZPT.

Table 1. The Response of the Number of Tillers to the Aplication of Liquid of Fertilizer and Plant Growth Regulators.

\begin{tabular}{lcccc}
\hline \multirow{2}{*}{$\begin{array}{l}\text { Perlakuan } \\
\text { Treatments }\end{array}$} & $\begin{array}{c}\text { Jumlah anakan } \\
\text { Number of Tillers }\end{array}$ \\
\cline { 2 - 5 } & $\begin{array}{c}\text { 14 HSP } \\
\text { (days after } \\
\text { reaping) }\end{array}$ & $\begin{array}{c}\text { 21 HSP } \\
\text { (days after } \\
\text { reaping) }\end{array}$ & $\begin{array}{c}\text { 28 } \mathrm{HSP} \\
\text { (days after } \\
\text { reaping) }\end{array}$ & $\begin{array}{c}\text { 35 HSP } \\
\text { (days after } \\
\text { reaping) }\end{array}$ \\
\hline Kontrol/Control & $2,8 \mathrm{a}$ & $3,0 \mathrm{a}$ & $3,9 \mathrm{a}$ & $4,6 \mathrm{a}$ \\
ZPT 14 ml/L & $2,9 \mathrm{a}$ & $3,2 \mathrm{a}$ & $3,5 \mathrm{a}$ & $4,0 \mathrm{a}$ \\
POC $3 \mathrm{ml} / \mathrm{L}$ & $3,5 \mathrm{a}$ & $3,9 \mathrm{a}$ & $4,9 \mathrm{~b}$ & $5,2 \mathrm{~b}$ \\
ZPT 14 ml/L dan POC 3 & & & $11,4 \mathrm{c}$ & $11,7 \mathrm{c}$ \\
ml/L & $7,5 \mathrm{~b}$ & $8,0 \mathrm{~b}$ & & 0,6 \\
\hline Nilai BNT \% & 2,3 & 2,1 & 0,5 & 0,6 \\
\hline
\end{tabular}

Keterangan:

Angka-angka yang diikuti oleh huruf yang berbeda menunjukkan berbeda nyata pada uji BNT 5\%. 
Hasil menunjukkan padi salibu yang diberi perlakuan ZPT dan POC mampu menghasilkan jumlah anakan tertinggi dibandingkan perlakuan lainnya. Pada pengamatan 14 HSP, padi yang diberi perlakuan ZPT dan POC secara bersamaan mampu menghasilkan jumlah anakan sebanyak $62 \%$ dibandingkan tanaman padi yang tidak diberi perlakuan apapun (kontrol). Sedangkan untuk tanaman padi yang diberi perlakuan hanya ZPT atau POC peningkatan jumlah anakan yang diperoleh adalah $61 \%$ dan $53 \%$ dibandingkan tanaman padi salibu yang diberi perlakuan campuran ZPT dan POC. Hal ini disebabkan kandungan unsur hara lengkap yang terdapat pada POC dan ZPT diantaranya nitrogen, fosfor, dan kalium. Tiga unsur hara tersebut merupakan unsur yang paling banyak dibutuhkan tanaman padi untuk dapat memicu pertumbuhan awal (Anam et al., 2019). Munir et al. (2018) menjelaskan POC yang diaplikasikan kepada tanaman dengan konsentrasi $20 \%$ setiap minggu mapu meningkatkan pertumbuhan dan hasil padi ladang atau sawah jika dibandingkan dengan tanaman padi yang beri pupuk cair komersial. Dengan perpaduan antara ZPT dan POC yang dicampur secara langsung dan diaplikasikan ke tanaman padi dapat meningkatkan kandungan asam amino dalam tanah. Pertumbuhan tanaman dan enzim membutuhkan sumber protein dalam metabolismenya yang pembentukan protein tersebut berasal dari asam amino (Supartha et al., 2012). Asam amino ini dapat memacu aktivitas fotosintesis, pertumbuhan akar dan jumlah klorofil. Selain itu asam amino dapat mengendalikan transpirasi tanaman serta mengatur stomata dengan optimal.

Kelebihan dari pupuk organik yaitu adanya kandungan unsur hara mikro yang lengkap. Unsur hara mikro berfungsi sebagai activator system enzyme seperti respirasi dan fotosintesis sehingga memicu pembentukan anakan yang baru pada tanaman padi. Purba (2015) menjelaskan pupuk organik cair dapat mengsubstitusi kebutuhan pupuk kimia secara umum seperti pembentukan anakan dan tinggi tanaman yang setara dengan pemberian pupuk kimia NPK. Pada pertanian padi secara organik dianjurkan untuk menggunakan pupuk organik cair yang dikombinasikan dengan ZPT. Kombinasi tersebut berperan penting untuk menambah sekaligus melengkapi unsur hara yang dibutuhkan sekaligus memberi stimulus tanaman guna pemanjangan sel (Puspadewi et al., 2016). Selain unsur hara makro terdapat juga unsur hara mikro yang memiliki peranan penting pada pertumbuhan tanaman padi salibu. Unsur hara mikro yang terkandung pada pupuk organik cair seperti $\mathrm{Zn}$ dan $\mathrm{Cu}$ dapat menambah tinggi tanaman. Kedua unsur tersebut berperan dalam metabolisme tanaman. Unsur $\mathrm{Cu}$ atau tembaga merangsang keaktifan enzim dalam transformasi asimilat dari daun serta menyerap $\mathrm{N}$ selama fase vegetatif tanaman (Istiqomah et al., 2016).

Pola yang sama juga terlihat saat tanaman berumur 21 HSP. Perlakuan kontrol, ZPT, dan POC yang di aplikasikan pada tanaman tidak menunjukkan hasil yang berbeda nyata. Sedangkan untuk perlakuan campuran ZPT dan POC mampu memberikan jumlah anakan paling banyak. Pada umur 28 dan 35 HSP menunjukkan pola yang sedikit berbeda dibandingkan saat umur tanaman 14 dan 21 HSP. Pada pengamatan padi umur $28 \mathrm{HSP}$, perlakuan kontrol dan pemberian ZPT menunjukkan hasil yang tidak berbeda nyata, namun pemberian 2 perlakuan tersebut nyata lebih rendah dibandingkan tanaman ketika diberi perlakuan POC. Terjadi peningkatan jumlah anakan sebanyak $20 \%$ dan $28 \%$ pada perlakuan kontrol dan ZPT jika dibandingkan dengan pemberian POC. Walaupun demikian, pemberian ZPT dan POC secara bersamaan mampu 
menghasilkan jumlah anakan yang lebih tinggi dibandingkan perlakuan lainnya. Hal yang serupa juga ditunjukkan saat tanaman berumur 35 HSP. Tanaman padi salibu yang diberi perlakuan ZPT dan POC secara bersamaan menghasilkan jumlah anakan paling banyak dibandingkan perlakuan lainnya. Pengaplikasian pupuk organik cair (POC) pada tanaman padi dapat mempercepat sintesis asam amino dan protein sehingga dapat mempercepat pertumbuhan tanaman. Pupuk organik cair mengandung unsur kalium yang memiliki peran dalam metabolisme tanaman seperti sintesis protein dari ion ammonium serta asam amino. Selain itu kalium juga berperan dalam pemanjangan sel dan memelihara tekanan turgor (Yasin, 2016).

\section{Tinggi Tanaman}

Bertambahnya tinggi tanaman merupakan salah satu proses fisiologi yang mana pada proses tersebut sel melakukan pembelahan dan pemanjangan. Proses tersebut sebagai bentuk dari adanya pengaruh tanaman terhadap lingkungan sekitarnya. Pengaruh konsentrasi pupuk organik cair dan ZPT pada tinggi tanaman padi Salibu disajikan pada Tabel 2. Hasil analisis sidik ragam menunjukkan bahwa adanya pengaruh nyata untuk semua umur pengamatan pada tanaman padi salibu.

Tabel 2. Respon Tinggi Tanaman Terhadap Pemberian POC dan ZPT

Table 2. The response of Plant Height to the Aplication of Liquid of Fertilizer and Plant Growth Regulators.

\begin{tabular}{|c|c|c|c|c|}
\hline \multirow[b]{2}{*}{$\begin{array}{l}\text { Perlakuan } \\
\text { Treatments }\end{array}$} & \multicolumn{4}{|c|}{$\begin{array}{l}\text { Tinggi Tanaman }(\mathrm{cm}) \\
\text { Plant Height }(\mathrm{cm})\end{array}$} \\
\hline & $\begin{array}{l}14 \text { HSP } \\
\text { (days after } \\
\text { reaping) }\end{array}$ & $\begin{array}{l}21 \mathrm{HSP} \\
\text { (days after } \\
\text { reaping) }\end{array}$ & $\begin{array}{l}28 \text { HSP } \\
\text { (days after } \\
\text { reaping) }\end{array}$ & $\begin{array}{l}35 \text { HSP } \\
\text { (days after } \\
\text { reaping) }\end{array}$ \\
\hline Kontrol / Control & $40,5 \mathrm{a}$ & $49,5 \mathrm{a}$ & $55,0 \mathrm{c}$ & $63,0 \mathrm{~b}$ \\
\hline ZPT 14 ml/L & $36,2 \mathrm{a}$ & $44,7 \mathrm{a}$ & $43,7 \mathrm{a}$ & $56,5 \mathrm{a}$ \\
\hline $\mathrm{POC} 3 \mathrm{ml} / \mathrm{L}$ & $36,5 \mathrm{a}$ & $45,5 \mathrm{a}$ & $51,0 \mathrm{~b}$ & 56,0 a \\
\hline ZPT $14 \mathrm{ml} / \mathrm{L}$ dan POC 3 & & & $66,0 \mathrm{~d}$ & $75,0 \mathrm{c}$ \\
\hline $\mathrm{ml} / \mathrm{L}$ & $49,5 \mathrm{~b}$ & $57,5 \mathrm{~b}$ & & \\
\hline Nilai BNT \% & 6,4 & 6,4 & 3,4 & 3,2 \\
\hline
\end{tabular}

Keterangan:

Angka-angka yang diikuti oleh huruf yang berbeda menunjukkan berbeda nyata pada uji BNT 5\%.

Tanaman padi saat umur 14 HSP menunjukkan tinggi tanaman yang tidak berbeda nyata ketika tanaman diberi perlakuan kontrol, ZPT, dan POC. Akan tetapi saat tanaman diberi perlakuan ZPT dan POC secara bersamaan, tanaman padi menunjukkan tinggi yang nyata lebih tinggi dibandingkan ketiga perlakuan lainnya. Terjadi pertambahan tinggi tanaman sebesar $18 \%$ ketika tanaman diberi perlakuan ZPT dan POC secara bersamaan dibandingkan dengan perlakuan kontrol. Pola yang serupa juga terlihat saaat tanaman berumur 21 HSP. Pemberian ZPT dan POC secara bersamaan dapat memberikan tinggi tanaman yang signifikan dibandingkan perlakuan lainnya.

Saat tanaman berumur 28 HSP tinggi tanaman menunjukkan hasil yang berbeda nyata untuk setiap perlakuan. Tinggi terendah di hasilkan oleh tanaman yang diberi perlakuan ZPT saja sedangkan untuk tanaman yang memiliki tinggi paling tinggi dimiliki oleh tanaman yang diberi perlakuan campuran ZPT dan POC 
secara bersamaan. Perlakuan kontrol menunjukkan hasil yang nyata lebih tinggi dibandingkan perlakuan ZPT atau POC. Pada pengamatan 35 HSP justru menunjukkan bahwa perlakuan kontrol nyata lebih tinggi dibandingkan perlakuan ZPT atau POC. Walaupun demikian tanaman yang diberi perlakuan ZPT dan POC secara bersamaan memilik tinggi tanaman lebihh tinggi dibandingkan dengan perlakuan lainnya. Perlakuan kombinasi ZPT dan POC memiliki peranan masing-masing dalam memenuhi kebutuhan nutrisi tanaman. ZPT yang diberikan dalam penelitian ini berbahan dasar dari air kelapa yang memiliki kandungan auksin dan sitokinin sebagai hormon pertumbuhan sedangkan POC berfungsi dalam memenuhi unsur hara serta perbaikan lingkungan tumbuh tanaman itu sendiri.

Mekanisme kerja hormon auksin kaitannya dalam mempengaruhi pemanjangan sel tanaman adalah auksin yang berperan dalam memacu protein yang ada di membran plasma sel untuk memompa ion $\mathrm{H}^{+}$. Penggunaan air kelapa dalam pemanfaatannya sebagai ZPT alami guna meningkatkan pertumbuhan tanaman. Hormon tersebut memiliki peran memicu terjadinya pembelahan sel, diferensiasi jaringan, pemanjangan sel tunas pucuk (Saefas et al., 2017). Air kelapa memiliki kandungan seperti unsur mineral, magnesium, ferum, sulfur, cuprum dan kalium sebagai nutrisi dalam pertumbuhan tanaman (Ariyanti et al., 2018). Adanya kandungan kalium pada air kelapa dapat memperlancar masuknya nutrisi dengan mengatur proses menutup membukanya stomata daun (Muslimah et al., 2016). Pernyataan tersebut juga didukung Rosniawaty et al. (2018) yang menjelaskan air kelapa dapat memicu dan menyebabkan terjadinya pembentukan tunas dan diferensiasi sel. air kelapa yang dipilih adalah air kelapa muda dikarenakan air kelapa yang tua memiliki sifat asam (Torar, 2010). Konsentrasi air kelapa yang terkandung dalam ZPT ini sudah sesuai dengan literasi yang ada. Referensi juga menunjukkan bahwa ZPT dapat diberikan dalam konsentrasi yang rendah.

\section{KESIMPULAN}

Berdasarkan hasil penelitian dapat disimpulkan bahwa Pemberian POC yang dikombinasikan dengan ZPT mampu memberikan pertumbuhan yang baik pada tanaman padi salibu. Tanaman padi salibu yang diberi perlakuan POC dan ZPT secara bersamaan mampu meningkatkan tinggi tanaman $16 \%$ dan jumlah anakan sebesar $60 \%$.

\section{DAFTAR PUSTAKA}

Anam, C., Ratnawida, D. A., \& Qibtiyah, E. M. (2019). Kajian Macam Pupuk Majemuk dan Organik Cair Terhadap Pertumbuhan dan Produksi Tanaman Padi (Oryza sativa L.). Agroradix, 3(1), 20-28.

Ariyanti, M., Suherman, C., Maxiselly, EQ Y., \& Rosniawaty, S. (2018). Pertumbuhan Tanaman Kelapa (Cocos nucifera L.) Dengan Pemberian Air Kelapa. JURNAL HUTAN PULAU-PULAU KECIL, 2(2), 201-212.

Istiqomah, N., Mahdiannoor, \& Asriati, F. (2016). Pemberian Berbagai Konsentrasi Pupuk Organik Cair (POC) Terhadap Pertumbuhan dan Hasil Padi Ratun. ZIRAA'AH, 41(3), 296-303.

Iswahyudi, Budiono, A., \& Wildani, A. (2017). Pendampingan Penggunaan Pupuk Organik (Eco Farming) Pada Kelompok Tani Palem Desa Sumedangan Kabupaten Pamekasan. Prosiding Seminar Nasional Hasil Pengabdian Kepada Masyarakat Universitas Islam Madura, 22-25. 
Munir, J., Kurniawan, B., \& Zahanis, Z. 的 (2018). Pengaruh Pupuk Organik Cair Unitas Super Asal Chromolaena odorata Terhadap Pertumbuhan dan Hasil Padi Hitam (Oryza sativa L.). JURNAL AGROTEKNOLOGI, 8(2), 15-20.

Muslimah, Y., Putra, I., \& Diana, L. (2016). Pengaruh Jenis dan Konsentrasi Zat Pengatur Tumbuh Organik Terhadap Pertumbuhan Stek Lada (Piper nigrum L.). Jurnal Agrotek Lestari, 2(2), 27-36.

Purba, R. (2015). Kajian Pemanfaatan EQ Pupuk Organik Pada Usahatani Padi Sawah Di Serang Banten. Agriekonomika, 4(1), 59-65.

Puspadewi, S., Sutari, W., \& Kusumiyati. (2016). Pengaruh Konsentrasi Pupuk Organik Cair (POC) dan Dosis Pupuk N, P, K terhadap Pertumbuhan dan Hasil Tanaman Jagung Manis (Zea mays L. Var Rugosa Bonaf) Kultivar Talenta. Jurnal Kultivasi, 15(3), 208-216.

Rosniawaty, S., Anjarsari, I. R. D., \& EQ Sudirja, R. (2018). Aplikasi Sitokinin untuk Meningkatkan Pertumbuhan Tanaman Teh di Dataran Rendah. Jurnal Tanaman Industri Dan Penyegar, 5(1), 31-38.

Saefas, S. A., Rosniawaty, S., \& 期 Maxiselly, Y. (2017). Pengaruh Konsentrasi Zat Pengatur Tumbuh Alami dan Sintetik terhadap Pertumbuhan Tanaman Teh (Camellia sinensis (L.) O. Kuntze) Klon GMB 7 setelah Centering. Kultivasi, 16(2).

Supartha, I. N. Y., Wijayana, G., \& EQ Adnyana, G. M. (2012). Aplikasi Jenis Pupuk Organik pada Tanaman Padi Sistem Pertanian Organik. Agroekoteknologi Tropika, 1(2), 98-
106.

Torar, D. J. (2010). Adopsi Teknologi Dan Analisis Finansial Pada Pengolahan Minuman Ringan Dan Sirup Air Kelapa Di Kabupaten Minahasa. Buletin Palma, 38, 17-23.

Triyogi, A., Widiyantono, D., \& E Kusumaningrum, A. (2018). Strategi Pengelolaan Dana Bantuan Sosial Pengembangan System Of Rice Intensification di Kecamatan Bener Kabupaten Purworejo. SURYA AGRITAMA, 7(1), 106-119.

Yasin, S. M. (2016). Respon Pertumbuhan Padi (Oryza sativa L.) Pada Berbagai Konsentrasi Pupuk Organik Cair Daun Gamal. Jurnal Galung Tropika, 5(1), 20-27. 